\title{
DEATH AS A BARGAINING CHIP: PLEA BARGAINING AND THE FUTURE OF VIRGINIA'S DEATH PENALTY
}

\author{
John G. Douglass *
}

Virginia now averages less than a single death sentence each year, ${ }^{1}$ a far cry from its not-too-distant history as the second most active death penalty state in the nation. ${ }^{2}$ The numbers alone tempt us to forecast the death of Virginia's death penalty: a death by disuse. But those numbers leave much of the story untold. The plummeting number of death sentences is only the diminishing tip of a larger, more stable iceberg of capital case litigation. That iceberg is melting very slowly, if at all.

Though death sentences are increasingly rare, capital indictments are not. Even as death sentences decline, capital charging in Virginia persists at a relatively stable rate. ${ }^{3}$ As a result, Virginia prosecutors now charge about twenty cases of capital murder annually for each case that results in a death sentence. ${ }^{4}$

What happens to the other nineteen cases? Plea bargaining fills much of that gap. Today, even more than in years past, Virginia's death penalty functions primarily as a bargaining chip in

* Professor of Law, University of Richmond School of Law. My thanks to David Johnson and Maria Jankowski for helpful insights. Thanks also to D.J. Geiger, the principal author of the Virginia Indigent Defense Commission Report, see infra Part I.D, for her thoroughness in assembling and organizing data on capital indictments. And thanks to Laura Joseph for very capable assistance with research.

1. Since 2004, Virginia courts have sentenced nine people to death. Death Sentences in the United States from 1977 by State and by Year, DEATH PENALTY INFO. CTR., http:// www.deathpenaltyinfo.org/death-sentences-united-states-1977-2008 (last visited Feb. 27, 2015) [hereinafter Death Sentences by State/Year].

2. Virginia has executed 110 people in the post-1976 "modern" era of the death penalty. Number of Executions by State and Region Since 1976, DEATH PENALTY INFO. CTR., http://www.deathpenaltyinfo.org/number-executions-state-and-region-1976 (last visited Feb. 27, 2015) [hereinafter Executions by State]. Prior to 2014, that placed Virginia second behind Texas's 508 executions. Id. In 2014, Oklahoma executed three individuals and now occupies second position with 111 executions. Id.

3. Va. Indigent Def. Comm'n, Review of the CAPital Defender Offices apps. A, B (2013) [hereinafter VIDC REvIEW]; see infra Part I.D.

4. Id. 
a plea negotiation process that resolves most capital litigation with sentences less than death. ${ }^{5}$ Virginia prosecutors have not abandoned the death penalty. Instead, increasingly, they bargain with it.

This reality has important implications for the future of Virginia's death penalty. This symposium essay addresses two related concerns. The first relates to fairness. The second relates to cost.

First, fairness. Because charging and plea negotiation decisions are made by independently elected commonwealth's attorneys across Virginia, and because different prosecutors make those decisions very differently, it has long been true that the locality where a murder occurs is a principal factor in determining who gets death, and who gets life. ${ }^{6}$ While plea negotiations may bring fewer death sentences, an imbalance remains across jurisdictions in both capital indictments and death sentences. ${ }^{7}$ If our aim is like treatment of like cases across the Commonwealth, we remain a long way from achieving that aim.

This leads to a second concern: cost. Because so many capital cases are resolved by post-indictment plea bargaining, after much of the time-consuming work of investigators, prosecutors, defense counsel, and experts has already taken place, the financial costs of our death penalty system will remain relatively high, despite the decline in actual death sentences. ${ }^{8}$ In a world of limited resources and tight budgets, that cost is likely to attract increasing concern.

5. See infra Part I.D.

6. See Joint Legis. Audit \& Rev. Comm'n of the VA. Gen. Assembly, Review of VIRGINIA's SYSTEM OF CAPITAL PUNISHMENT 27-31, (2002) [hereinafter JLARC REPORT], available at jlarc.virginia.gov/reports/Rpt274.pdf; infra Part I.F.

7. See infra Part I.F.

8. See Adam M. Gershowitz, Pay Now, Execute Later: Why Counties Should Be Required to Post a Bond to Seek the Death Penalty, 41 U. RICH. L. REv. 861, 861-66 (2007) (discussing the cost-benefit "disconnect" in a national context). Many of those costs are borne by statewide budgets rather than by local taxpayers. Id. at 864 . But the bargaining "advantages" of the death penalty are not spread evenly across the state. Id. at 862-63. Those advantages go only to prosecutors willing to use death as a bargaining chip, and most heavily to those who use that chip routinely. Id. at 876-77. Hence there is a political "disconnect" between those who seek the advantage of death bargaining and those who bear the costs. Id. As cost-related arguments gain prominence in the death penalty debate, this "disconnect" may emerge as a central element in that debate. Id. at 893 . The many are paying for the tactical advantage of the few. 
gotiation decisions vealth's attorneys irs make those dethat the locality determining who iations may bring cross jurisdictions :es. ${ }^{7}$ If our aim is wealth, we remain e so many capital aining, after much osecutors, defense he financial costs vely high, despite orld of limited reattract increasing he state. Id. at 862-63. a bargaining chip, and Hence there is a political rgaining and those who he death penalty debate, e. Id. at 893 . The many

Modest and achievable reforms would both promote fairness and reduce costs with little impact on current sentencing outcomes. That kind of reform should interest policymakers regardless of their views on the death penalty. This symposium essay concludes by outlining those possibilities for the future.

\section{The Past and Present: Capital Charging Persists at A RELATIVELY StABLE RATE IN ViRginia WHILE PleA BARGAinING INCREASINGLY RESOLVES CASES SHORT OF DEATH SENTENCES}

\section{A. The Decline of Death Sentences}

The numbers tell us that the death penalty is in retreat across the world, across the United States, and in Virginia. ${ }^{9}$ Viewed in light of human history across centuries, the decline of capital punishment is unmistakable. ${ }^{10}$ After all, Henry VIII's royal courts condemned more prisoners to death in an average week than Virginia sentenced to death in the past decade. ${ }^{11}$ In the United States, death sentences have declined for most of the past twenty years. ${ }^{12}$ Since a post-Furman ${ }^{13}$ high of over 300 death sentences per year in the mid-1990s, death sentences have dropped steadily to about eighty per year. ${ }^{14}$

9. Steven Pinker, The Better Angels of Our Nature: Why Violence has DECLINED 149-50 (2011); Death Sentences by State/Year, supra note 1.

10. PINKER, supra note 9, at 149-53.

11. Compare PINKER, supra note 9, at 149 (discussing Henry VIII's rate of execution), with Executions by State, supra note 2 (showing a consistent decline in death penalty use in the United States). Most of the world, and virtually all of Europe, has abolished death as a punishment for crime. PINKER, supra note 9, at 149-50. Six American states have abolished capital punishment in the past decade. States With and Without the Death Penalty, DEATH PENALTY INFO. CTR., http://www.deathpenaltyinfo.org/states-and-withoutdeath-penalty (last visited Feb. 27, 2015). Not surprisingly, observers typically look at these numbers and predict a future with no death penalty. See PINKER, supra note 9, at 150 53 (discussing reasons for the movement away from the death penalty internationally, and finding that abolishing death as a punishment had no observable consequences). To some, the future is now: "[E]ven the American death penalty, for all its notoriety, is more symbolic than real," writes Steven Pinker in his comprehensive study of human violence. Id. at 150.

12. See Death Sentences by Year: 1976-2012, DeATH Penalty Info. CTR., http:// www.deathpenaltyinfo.org/death-sentences-year-1977-2009 (last visited Feb. 27, 2015) [hereinafter Death Sentences by Year].

13. Furman v. Georgia, 408 U.S. 238, 239-40 (1972) (holding that the death penalty as implemented in several states would "constitute cruel and unusual punishment in violation of the Eighth and Fourteenth Amendments").

14. Death Sentences by Year, supra note 12. 
Virginia's recent history mirrors the national trend. For three decades following Furman, Virginia executed more people than any state but Texas, ${ }^{15}$ and did so more "efficiently"-meaning a higher percentage of death sentences resulted in execution, and did so more quickly after death sentence-than any other state. ${ }^{16}$ From 1995 to 1999, Virginia courts were still averaging about five death sentences per year. ${ }^{17}$ Since 2004 , however, death sentences in those same courts diminished to less than one per year. ${ }^{18}$ Since the sentencing of Robert Charles Gleason, Jr. in $2011,{ }^{19}$ Virginia has produced no new death sentences. ${ }^{20}$

\section{B. The "Funneling" Process in Capital Cases}

While death sentences are in steep decline, death penalty cases are not. The docket of capital litigation in Virginia remains much larger than the comparatively few death sentences that it produces. ${ }^{21}$ This is because most capital cases are resolved before trial through a "winnowing" or "funneling" process. ${ }^{22}$ At the top of the funnel, the process begins with dozens of arrests for capitaleligible crimes. ${ }^{23}$ As cases move down the funnel through indictment and pretrial litigation, we see capital cases turned into noncapital dispositions, sometimes through unilateral prosecutorial choice, but most often by a negotiated guilty plea to something

15. Executions by State, supra note 2 .

16. See Am. Bar Ass'n, Evaluating Fairness and Accuracy in State Death Penalty Systems: The Virginia DeAth Penalty Assessment RePort 1 (2013) [hereinafter ABA Assessment]; King Salim Khalfani \& Stephen A. Northup, Virginia and the Death Penalty, DAILY PROGREss (Jan. 23, 2013), http://www.dailyprogress.com/news/vir ginia-and-the-death-penalty/article_9a0b7dce-75f7-5364-940a-ba2236e2545b.html?mode= jqm ("The average time between conviction and execution in Virginia is less than eight years, by far the shortest in the nation.").

17. Death Sentences by State/Year, supra note 1.

18. Id.

19. Gleason, a death row prisoner who killed another inmate, told the court he would kill again and essentially asked for the death penalty. See Gleason v. Commonwealth, 726 S.E.2d 351, 352, 354 (Va. 2012).

20. Virginia Capital Litigation Data, VA. CAP. CASE Clearinghouse, http://www. ve3.org/resources/page.asp?pageid=561 (last visited Feb. 27, 2015) [hereinafter VCCC Da$t a]$ (compiling data in an excel spreadsheet accessible through the hyperlink).

21. See JLARC REPORT, supra note 6, at 16-17 (noting that from 1995-1999 out of 215 capital-eligible cases only 24 resulted in death sentences).

22. For a visual depiction of this "funnel," see $i d$. at II.

23. See id. at 16-17 (noting that from 1995-1999 there were 215 arrests that were eligible for capital punishment). 
1 trend. For three more people than sntly"-meaning a in execution, and 1 any other state. ${ }^{16}$ 'eraging about five $r$, death sentences te per year. ${ }^{18}$ Since in $2011,{ }^{19}$ Virginia

eath penalty cases inia remains much ices that it producsolved before trial ${ }^{22}$ At the top of the rrests for capitalnel through indictes turned into nonteral prosecutorial plea to something

UURACY IN STATE DEATH REPORT 1 (2013) [hereinafTorthup, Virginia and the lailyprogress.com/news/vir 22236e2545b.html?mode= Tirginia is less than eight

te, told the court he would son v. Commonwealth, 726

ARINGHOUSE, http://www. 15) [hereinafter VCCC $D a$ e hyperlink).

lat from 1995-1999 out of

less than a death sentence. ${ }^{24}$ At the narrow bottom of the funnel, a handful of cases go to trial where contests over guilt-or, more typically, over sentencing-winnow a bit more. ${ }^{25}$ Those contested cases produce a trickle of death sentences at the exit of the funnel. ${ }^{26}$

This funneling process has little to do with the legislature, or even the judiciary. It has a fair amount to do with the skill and tenacity of defense lawyers. It has lots to do with the discretion of prosecutors.

As for the legislature, Virginia's broad capital murder statute allows for a wide open entrance at the top of the funnel. ${ }^{27}$ Capital murder encompasses fifteen different categories of intentional homicide, ${ }^{28}$ including (the most frequently charged) killing in the commission of robbery. ${ }^{29}$ Steal the victim's wallet and "ordinary" murder becomes capital-eligible. ${ }^{30}$ Once the capital murder is proved, Virginia's statutory prerequisites for a death sentence leave plenty of room for discretion. The jury can vote death if it finds the defendant's conduct "vile, horrible or inhuman" or if it finds defendant "a continuing serious threat to society."

As for the judiciary, Virginia law provides two opportunities for courts to participate in the funneling process by exercising judgment that a case does not merit a death sentence. ${ }^{32}$ First, after a jury votes death, a Virginia court may set aside the death sentence and impose a life sentence. ${ }^{33}$ That power is entirely discretionary and may be exercised "upon good cause shown."

24. See, e.g., id. at 43 .

25. See id. at 16-17; Sherod Thaxton, Leveraging Death, 103 J. CRIM. L. \& CRIMINOLOGY 475, 487-88 (2013) (discussing the incentives for going to trial in deathpenalty cases).

26. See JLARC REPORT, supra note 6, at 17.

27. See id. at 14 (recognizing the increase in capital-eligible arrests as a result of legislative expansion of the capital murder statute).

28. VA. CODE ANN. § 18.2-31 (Repl. Vol. 2014). Virginia's history of expanding the number of offenses eligible for the death penalty is outlined in ABA ASSESSMENT, supra note 16, at 5 \& n.37.; see also JLARC Report, supra note 6, at 8-11.

29. VA. CODE ANN. § 18.2-31; see JLARC REPORT, supra note 6, at 16, 30.

30. See VA. CODE ANN. § 18.2-31.

31. Id. § 19.2-264.2.

32. Notably, Virginia courts have no discretion before trial to determine that death is an inappropriate punishment. See In re Horan, 634 S.E.2d 675, 678-79 (Va. 2006).

33. See VA. CODE ANN. § 19.2-264.5.

34. Id. 
Second, the Supreme Court of Virginia must review every death sentence to determine whether it is "excessive or disproportionate." ${ }^{35}$ Though legislation explicitly grants these judicial powers, courts almost never exercise them to winnow out questionable death sentences. Of the dozens of death sentences voted by juries in the post-Furman decades, Virginia trial judges have found "good cause" to set aside only a tiny fraction. ${ }^{36}$ And the Supreme Court of Virginia has never found a death sentence "excessive or disproportionate." 37

At trial, of course, juries typically make the ultimate choice of life or death, ${ }^{38}$ but the vast majority of capital cases never get to a jury verdict. ${ }^{39}$ Most of the funneling occurs before that. ${ }^{40}$ Fifteen to twenty years ago, prosecutors winnowed out about $60 \%$ of capital murder indictments before trial with-usually bargained forchoices not to seek death. ${ }^{41}$ Now that winnowing process disposes of close to $90 \%$ of capital murder indictments. ${ }^{42}$ Virginia juries ul-

35. Id. § 17.1-313(C).

36. I have found no record of a Virginia trial court reducing a jury verdict of death penalty to a lesser sentence based on "good cause." Accounts of practitioners suggest it almost never happens. The ABA assessment does not mention any case where such a reduction occurred. See generally ABA ASSESSMENT, supra note 16 (lacking any example of a court's exercising its discretion under Virginia Code section 19.2-264.5).

37. See ABA AsSESSMENT, supra note 16, at 218; JLARC REPORT, supra note 6, at IV (noting that none of 119 death sentences in its study were found disproportionate by the Supreme Court of Virginia); see also VA. CODE ANN. § 17.1-313(C). In theory at least there are scenarios in which Virginia trial judges play a role in selecting life or death. If the case is tried to the court without a jury, the judge has the power to sentence. But in Virginia both parties must waive jury before the court is empowered to try and sentence. A prosecutor seeking a death sentence is unlikely to concur in a jury waiver where he believes the court is inclined to life. And a defendant is unlikely to waive a jury in front of a judge inclined toward a death sentence. Hence jury waivers, when they occur, tend to come as part of an agreement where the prosecutor agrees not to pursue death. In a few cases where the evidence of guilt is clear and the defendant calculates the chances for a life sentence are stronger without a jury, defendants have entered guilty pleas to capital murder (i.e., without a plea agreement binding on the court) and courts have sentenced to life. The risk in that tactic, of course, is that the defendant acknowledges guilt with no guarantee that he will avoid a death sentence. See Dubois v. Commonwealth, 435 S.E.2d 636, 639 (Va. 1993) (affirming a death sentence entered by a trial judge following a guilty plea despite the commonwealth's recommendation of a life sentence).

38. The JLARC report documented jury sentencings in $53 \%$ of cases where the prosecutor sought death all the way through a contested verdict. JLARC REPORT, supra note 6, at 49,52 .

39. See id. at $16-17$.

40. See id. at 16.

41. See id. at II, 35-36, 40-41 (finding that prosecutors actively sought the death penalty through a contested verdict in only 64 of 170 cases indicted as capital murder).

42. See infra Part I.D. 
nust review every essive or disproporthese judicial pownow out questionasentences voted by - trial judges have ction. ${ }^{36}$ And the Suath sentence "exces-

e ultimate choice of cases never get to a ore that. ${ }^{40}$ Fifteen to bout $60 \%$ of capital lly bargained foring process disposes ${ }^{42}$ Virginia juries ul-

ing a jury verdict of death practitioners suggest it ally case where such a reduc(lacking any example of a 2-264.5).

REPORT, supra note 6 , at IV and disproportionate by the (C). In theory at least there ing life or death. If the case o sentence. But in Virginia try and sentence. A proseaiver where he believes the a jury in front of a judge inoccur, tend to come as part leath. In a few cases where chances for a life sentence leas to capital murder (i.e., ve sentenced to life. The risk ruilt with no guarantee that h, 435 S.E.2d 636, 639 (Va. lowing a guilty plea despite

$\%$ of cases where the proseARC REPORT, supra note 6,

tively sought the death pen$d$ as capital murder). timately decide life or death in only about $8 \%$ of indicted capital murder cases. ${ }^{43}$

Prosecutors, more than legislators, courts, or juries, control the funnel. Virginia commonwealth's attorneys control the entrance to the funnel when they decide whether to present an indictment for capital murder to a grand jury. ${ }^{44}$ After a capital indictment is filed and defense counsel is appointed, negotiations between prosecutors and defense attorneys largely determine whether a defendant will ever face a trial or sentencing where death is actually contested. ${ }^{45}$

\section{Winnowing by the Numbers: A Tale of Two Studies}

Before I get too deep into the numbers, I will offer a few words about the sources and the limits of the data I have examined.

First, a word about sources: In large measure, the numbers come from two studies undertaken more than a decade apart. The studies offer snapshots of death penalty case processing in Virginia during two (roughly) five-year periods, 1995 to 1999 and 2008 to 2013, and hence give us some idea of trends across almost twenty years.

The first study was published in 2002 by the Joint Legislative Audit and Review Commission of the Virginia General Assembly ("JLARC"). ${ }^{46}$ JLARC undertook the study in response to concerns about the uneven exercise of prosecutorial discretion in the application of Virginia's death penalty. ${ }^{47}$ JLARC staff reviewed data from Virginia State Police arrests, Sentencing Commission records of case dispositions, and-in a smaller sample of casescommonwealth's attorneys' case files. ${ }^{48}$ The JLARC data covered capital crimes occurring between 1995 and 1999. ${ }^{49}$ To date, the

43. Id.

44. See JLARC REPORT, supra note 6, at IV, 17.

45. See Susan Ehrhard, Plea Bargaining and the Death Penalty: An Exploratory Study, 29 JUST. SYS. J. 313, 323 (2008).

46. JLARC REPORT, supra note 6, at I.

47. The principal concern giving rise to the JLARC study was the perception of racial disparity in capital punishment. The principal conclusion of the study, however, was that prosecutors in highly populated localities were much less likely to seek the death penalty than their counterparts in less populated jurisdictions. Id. at Preface, iii-iv, 28.

48. Id. at 19-23.

49. Id. at 12, 19. JLARC chose 1995 as the starting point because that was the year 
JLARC study remains the most comprehensive study of prosecutorial discretion in Virginia death penalty cases. ${ }^{50}$

The second study was documented in a 2013 report by the Virginia Indigent Defense Commission ("VIDC") to the General Assembly, and it analyzed the caseloads of the four regional Capital Defender Offices ("CDOs") that defend a substantial portion of Virginia's capital cases. ${ }^{51}$ During the 2013 session, the General Assembly directed VIDC to undertake a study in order to determine whether, in light of the declining number of death sentences, resources committed to capital defense should be reallocated to other tasks. ${ }^{52}$ VIDC staff combed through court records and CDO case files to identify capital cases charged from 2008 through October 2013. ${ }^{53}$ VIDC found that, despite declining death sentences, the workload at regional CDOs remained substantial. ${ }^{54}$ The reason is that the stream of indicted capital cases continues at a steady rate, even as death sentencing diminishes. ${ }^{55}$

Now, the disclaimer. Because the two studies used different data sources and sought to answer different questions, there is no simple, direct way to compare the two. While I am confident that the major trends in capital charging and plea bargaining that I identify are supported by the data, I do not claim to have undertaken the kind of thorough, case-by-case review that would be necessary for more precise conclusions. Nor do I claim that this short symposium essay undertakes the kind of detailed statistical analysis that this topic deserves. Hence, my first observation about the "future" of Virginia's death penalty is that we need

Virginia abolished parole. Id. Based on statements by a number of commonwealth's attorneys, JLARC believed that the option of life without parole had a significant impact on charging and plea decisions by prosecutors. Id. at 31 .

50. See id. at i-iii. The ABA assessment attempted a survey of charging practices by commonwealth's attorneys, but received few responses from prosecutors. ABA ASSESSMENT, supra note 16 , at xviii.

51. VIDC REVIEW, supra note 3 , at 2 .

52. Id. The author of this symposium essay serves as a member of the VIDC.

53. Id. at 4. VIDC's principal source was the Supreme Court of Virginia's Circuit Court Case Management System, though the study highlights important gaps in that information. Id. at 4-5. To fill those gaps VIDC staff sought additional data directly from Circuit Court Clerks and from CDO case files. Id.

54. Id. at 2 (concluding that the CDOs "are not overstaffed").

55. See id. at 6. 
ive study of prosecues. $^{50}$

13 report by the Vir) to the General Asour regional Capital ubstantial portion of iession, the General dy in order to deter,er of death sentenchould be reallocated $\mathrm{h}$ court records and charged from 2008 spite declining death nained substantial. ${ }^{54}$ jital cases continues ainishes. ${ }^{55}$

es used different dalestions, there is no I am confident that a bargaining that I laim to have underview that would be do I claim that this f detailed statistical ny first observation lty is that we need er of commonwealth's attorad a significant impact on

jey of charging practices by from prosecutors. $\mathrm{ABA}$

nber of the VIDC.

Court of Virginia's Circuit important gaps in that inditional data directly from more complete data and a comprehensive study of capital charging and plea bargaining patterns before we can fully assess these trends.

\section{Comparing Capital Indictment Rates and Capital Trial Rates Across Twenty Years: Capital Charging Holds Steady, but Capital Trials Diminish}

In examining the JLARC and VIDC studies, this symposium essay aims to compare, across a twenty-year period, the discretionary choices of Virginia prosecutors at two key stages in capital cases: the indictment stage and the pretrial (or plea bargaining) stage. First, when presented with an arrest for a capital crime, how often do Virginia prosecutors seek an indictment for capital murder? I will call that the "capital indictment rate." Second, once a capital indictment is filed, how often does the case make it to a contested verdict where the death penalty remains at issue? That's the "capital trial rate." By comparing capital indictment rates with capital trial rates, we can get a rough idea of how often capital charges are bargained away after indictment for a resolution less than death. Then, by comparing the data from the JLARC and VIDC studies, we can see how those choices have changed (or not changed) across a period of almost twenty years.

To calculate a capital indictment rate, JLARC first had to identify and count the capital-eligible murder arrests from which a prosecutor might select cases for capital indictment. ${ }^{56}$ That turned out to be a difficult task because arrest warrants and police databases do not readily indicate whether a murder includes the elements necessary to charge a capital crime. ${ }^{57}$ After substantial effort, including examination of individual case files, and even some interviews with commonwealth's attorneys, JLARC identified 215 arrests for capital-eligible crimes between 1995 and 1999, an average of forty-three per year. ${ }^{58}$

56. JLARC REPORT, supra note 6, at 31, app. C.

57. Id. at 14, 20. JLARC looked at state police records of 970 murder arrests in an effort to identify which were "capital eligible." But the arrest records do not distinguish among types of murder. Id. at 20. Hence, to "approximate" the number of capital-eligible arrests, JLARC staff undertook the labor-intensive task of reviewing Sentencing Commission data and indictments. Id. In some cases they even interviewed prosecutors. Id.

58. Id. at 14, 16-17, 19-20. 
Out of that universe of 215 eligible cases, Virginia prosecutors obtained capital murder indictments in 170 cases, an average of thirty-four per year. ${ }^{59}$ Hence JLARC calculated a capital indictment rate of $79 \% .{ }^{60}$ As JLARC summarized its finding, "nearly eight out of every 10 persons who were arrested for a capital eligible crime were indicted for capital murder." While that percentage may seem high, at least to those who feel the death penalty should be reserved for the "worst of the worst," JLARC's statistical findings were consistent with responses to surveys it sent to all 121 commonwealth's attorneys. Sixty percent responded that they "always seek a capital murder indictment when the elements of the offense warrant the charge." ${ }^{.62}$ JLARC's findings suggest that, at least as of the late 1990s, Virginia prosecutors on the whole were disinclined to "winnow out" many potential capital cases at the indictment stage.

Now let's move forward about fifteen years, through a period when death sentencing was declining by more than $80 \%{ }^{63}$ We might expect a parallel drop in the annual number of capital indictments from the JLARC average of thirty-four per year. ${ }^{64}$ But the decline is much more modest. The VIDC study counted 131 capital indictments from 2008 through October 2013, an average of about twenty-two per year. ${ }^{65}$ In other words, death charging declined by only about $35 \%$ even as death sentencing declined by $80 \%$. Death charging is declining much more modestly than death sentencing.

Still, we need to address another important variable before we can appreciate how little the capital indictment rate has changed over time. From how many capital-eligible arrests did prosecutors select those twenty-two per year for capital indictment? That question, unfortunately, is hard to answer directly without exam-

59. Id. at $16-17$.

60. Id. at 32 .

61. Id. at III.

62. Id. at 31 ; see also ABA ASSESSMENT, supra note 16, at 118 \& n.51 (quoting a news report of a commonwealth's attorney who often "charge[s] capital murder even if it's questionable as whether or not it fits in that category").

63. See Death Sentences by State/Year, supra note 3 (demonstrating a decline in death sentences from an average of five per year between 1995-1999 to less than one per year between 2004-2013).

64. See supra note 59 and accompanying text.

65. See VIDC REVIEW, supra note 3, at app. B. 
ining the individual facts of hundreds of murder arrests. But one key fact seems almost certain: the number of capital-eligible arrests has gone down-a lot-since the mid-1990s. ${ }^{66}$ That is because violent crime in general, and homicides in particular, has dropped dramatically across the past two decades. ${ }^{67}$ Using the midpoints of the JLARC study (1997) and the VIDC study (2010) as points of reference, the annual number of arrests for murder in Virginia has dropped from 424 to 293 , a decline of $30 \%{ }^{68}$ Assuming the rate of capital-eligible murders goes up or down roughly at the same rate as murders in general, that would suggest that the annual pool of capital-eligible murder arrests has shrunk by $30 \%$ during the years between the JLARC and VIDC studies. That would create an annual pool of about thirty capital-eligible murder arrests, from which Virginia prosecutors annually obtained twenty-two capital murder indictments. That results in a capital indictment rate of $73 \%$ for the years 2009 to 2013 , only a small step lower than the $79 \%$ calculated by JLARC for 1995 to 1999.

In sum, while capital indictments have declined by about a third from the late 1990s to the past few years, that decline is almost entirely attributable to the decline in violent crime across the same period. It is not because Virginia prosecutors are significantly more selective in their capital indictment decisions.

Now to the second question: the capital trial rate. How many of those capital murder cases actually get to a contested life-ordeath verdict? The JLARC study of 1995-1999 cases documented the winnowing of 170 capital murder indictments down to sixtyfour cases where prosecutors actively sought the death penalty

66. See, e.g., FBI, CRIME IN THE UNITED STATES 2013 tbl.1 (2014), available at http: //www.fbi.gov/about-us/cjis/ucr/crime-in-the-u.s/2013/crime-in-the-u.s.-2013/tables/1table datadecoverviewpdf/table_1_crime_in_the_united_states_by_volume_and_rate_per_10000 0_inhabitants_1994-2013.xls (indicating that the murder rate in the United States has declined from 9.0 murders per 100,000 inhabitants in 1994 to 4.5 murders per 100,000 inhabitants in 2013).

67. See id. (revealing that the number of violent crimes and murders in 2013 is significantly lower than the number of violent crimes and murders in 1994).

68. Compare FBI, CRIME IN THE UNITED STATES: 1997 UNIFORM CRIME REPORTS 286 tbl.69 (1998), available at http://www.fbi.gov/about-us/cjis/ucr/crime-in-the-u.s/1997/97sec 4.pdf, with FBI, CRIME IN THE UNITED STATES 2010, tbl.69 (2011), available at http://ww w.fbi.gov/about-us/cjis/ucr/crime-in-the-u.s/2010/crime-in-the-u.s.-2010/tables/10tbl69.xls. 
through a contested trial or sentencing. ${ }^{69}$ That's a capital trial rate of $38 \%{ }^{70}$

Both the number and the rate of capital trials have dropped significantly since 1999 . The available data on capital indictment dispositions from the VIDC study shows trials in about $19 \%$ of capital cases between 2008 and 2013. ${ }^{71}$ Even that number may substantially overstate the percentage of cases where the death penalty is actually contested through verdict. That is because half of those trials are bench trials. ${ }^{72}$ In Virginia, a trial to the court occurs only where both parties agree to waive a jury. ${ }^{73} \mathrm{~A}$ defendant's agreement to waive a jury sometimes accompanies a prosecutor's agreement not to argue for death. ${ }^{74}$

69. JLARC REPORT, supra note 6, at 17 fig.7.

70. If that number seems small think again. On average, noncapital cases go to trial at a much lower rate. Since parole was abolished in 1995, the rate of jury sentencing (which parallels the rate of jury trial) in felony cases has dipped well below $2 \%$, and has dropped to about $4 \%$ in cases of crimes against the person. See VA. CRIM. SENT'G COMM'N, 2013 ANNUAL REPORT 30-31 (2013) [hereinafter VCSC REPORT], available at http://www. vcsc.virginia.gov/2013AnnualReport.pdf.

71. The VIDC study itself did not analyze case dispositions. I was able to review the work papers for the VIDC study, which included spreadsheets from the Supreme Court of Virginia case management system, listing capital murder indictments from 2008 through 2013, and including the disposition in most cases. See Spreadsheets Listing Capital Murder Indictments from 2008 to 2013 (unpublished data) (on file with the Supreme Court of Virginia Case Management System). Where the spreadsheets did not record a disposition, I checked the Virginia Circuit Court Case Information website. Circuit Court Case Information, VA. CTS. CASE INFO., http://wasdmz2.courts.state.va.us/CJISWeb/circuit.jsp (last visited Feb. 27, 2015). Finally, I included dispositions reported by CDOs and reflected in Appendix C to the VIDC study. VIDC REVIEW, supra note 3, at app. C. From that collection of sources I was able to identify dispositions in 100 cases that had been indicted as capital murder. John G. Douglass, Totals w/CCM Data (unpublished research notes) (on file with author) [hereinafter Douglass Notes]. Of those, forty-three were resolved by guilty plea and twenty-four by nolle prosequi. Id. (In some of the nolle prossed cases I was able to identify a superseding indictment followed by guilty plea to a lesser charge). Nine other cases showed capital charges amended to first or second degree murder. Id. Five cases were listed as "other." Id. There were nine jury trials and ten tried by "judge with witnesses." Id. The breakdown of bench trials versus jury trials appears roughly constant since the JLARC study, which documented jury verdicts in $53 \%$ of cases where prosecutors sought death. See JLARC REPORT, supra note 6, at 49, 52 fig.18.

72. Douglass Notes, supra note 71 (indicating that there were nine jury trials and ten bench trials).

73. VA. CoDE ANN. § 19.2-257 (Cum. Supp. 2014)

74. See, e.g., Commonwealth v. Lassiter, 722 A.2d 657, 659 (Pa. 1998); Cary Aspinwall, Kevin Sweat Won't Face Death Penalty in Killings of Weleetka Girls, Fiancée, TULSA WORLD (July 11, 2014, 3:19 PM), http://www.tulsaworld.com/news/courts/kevin-sweat-wo n-t-face-death-penalty-in-killings-of/article_320f9865-98f3-5b7f-83c1-5e6408e5f383.html; Mark Walters, Judge Denies New Trial for Adams Man Convicted of Murder; Appeal Filed, EVENING SUN (Jan. 20, 2014, 10:37 AM), http://www.eveningsun.com/local/ci_24949615/ 
3. I was able to review the rom the Supreme Court of tments from 2008 through leets Listing Capital Murvith the Supreme Court of $d$ not record a disposition, Circuit Court Case Infor/CJISWeb/circuit.jsp (last by $\mathrm{CDO}$ s and reflected in app. C. From that collecthat had been indicted as lished research notes) (on $\mathrm{y}$-three were resolved by nolle prossed cases I was to a lesser charge). Nine degree murder. Id. Five ten tried by "judge with appears roughly constant f cases where prosecutors ce nine jury trials and ten tka Girls, Fiancée, TULSA ws/courts/kevin-sweat-wo 3c1-5e6408e5f383.html; of Murder; Appeal Filed, un.com/local/ci_24949615/

In sum, when presented with a capital-eligible crime, Virginia commonwealth's attorneys continue to seek capital indictments at a relatively steady rate. Since the late 1990 s, their capital indictment rate has dipped only slightly, from $79 \%$ to $73 \%$. $^{75}$ But as the years have passed, Virginia prosecutors increasingly have chosen not to pursue death all the way through a contested trial and sentencing. The capital trial rate has been sliced in half, from $38 \%$ to $19 \%$ and the jury trial rate is even lower. ${ }^{76}$ Juries now make the death penalty decision in only about 9\% of Virginia cases that start with a capital murder indictment. ${ }^{77}$

\section{E. Post-Indictment Plea Bargaining Increasingly Resolves Capital Cases Short of a Death Sentence}

An increasingly small percentage of capital murder indictments ultimately leads to a trial where death is at issue. Why? The most likely-perhaps the quite obvious-answer is plea bargaining.

Of course, not all of the winnowing that occurs after indictment and before trial is the result of agreement. Prosecutors sometimes make the unilateral decision to take death off the table. ${ }^{78}$ And

judge-denies-new-trial-adams-man-convicted-murder. Some of these bench trials, in the vocabulary of practitioners, are "slow guilty pleas." See, e.g., Lewis v. Mazurkiewicz, 915 F.2d 106, 109-10 (3d Cir. 1990).

75. Compare JLARC REPORT, supra note 6, at 17 fig.7 (showing that there were 170 capital murder indictments out of 215 capital-eligible offenses between 1995 and 1999 , indicating a capital indictment rate of $79 \%$ ), with VIDC REVIEW, supra note 3, at app. B (indicating that there were an average of twenty-two capital indictments per year between 2008 and 2013, which is a capital indictment rate of $73 \%$ assuming there were approximately thirty capital-eligible murder arrests per year during the same time frame).

76. Compare JLARC REPORT, supra note 6, at 17 fig. 7 (illustrating a winnowing of 170 capital murder indictments down to 64 cases of prosecutors seeking the death penalty, a capital trial rate of $38 \%$ ), with supra note 52 (tracing my analysis of trials in Virginia between 2008 and 2013, which reveals a 19\% capital trial rate).

77. My calculation of a 9\% jury trial rate for the years 2008 through 2013 appears roughly consistent with data from the Virginia Capital Case Clearinghouse ("VCCC"). The VCCC data documents seventeen jury trials in the seven years from 2005 through 2011, resulting in eight death sentences. See ABA ASSESSMENT, supra note 16, at 142 (citing VCCC Data). If we assume an annual rate of twenty-five capital indictments, seventeen jury trials in that span would amount to about $9 \%$ of cases.

78. See, e.g., Michael Gordon, State Will Not Seek Death Penalty Against Bianca Tanner's Boyfriend, CHARLOTTE OBSERVER (Nov. 20, 2014), http://www.charlotteobserv er.com/2014/11/20/5329443/state-will-not-seek-death-penalty.html\#.VG-4v1fF-I0; Elliot C. McLaughlin, Prosecution Will Not Seek Death Penalty in Georgia Hot Car Death, CNN (Oct. 9, 2014, 2:40 PM), http://www.cnn.com/2014/09/24/justice/georgia-ross-harris-hot-car- 
even defendants facing capital charges sometimes plead guilty "straight up" with no bargain in place. ${ }^{79}$ Still, the available data confirms what experience and anecdotal reports suggest: that such unilateral post-indictment decisions probably account for a small number of cases. ${ }^{80}$ The decline in capital trials results mostly from prosecutors' increasing willingness to trade capital charges for guilty pleas.

Why are Virginia prosecutors more willing to resolve capital cases short of a death sentence? Life without parole surely has made a difference. For many prosecutors, no doubt, the option of life without parole diminishes the need for death sentences by providing a means to ensure that the most dangerous offenders remain in prison for life. ${ }^{81}$ So, plea bargaining that tilts away from death seems increasingly likely once life without parole is on the table.

But life without parole only partially explains the decline in contested capital trials. Virginia abolished parole in $1995 .^{82}$ So, to the extent that the life-without-parole option impacts charging and plea bargaining, we would expect that the JLARC study of cases from 1995 to 1999 would already account for most of that

death-penalty/. I am unaware of data which would document how often such unilateral choices by prosecutors occur after a capital indictment. My conversations with practitioners, both prosecutors and defense attorneys, suggest they are relatively rare.

79. Virginia's latest death sentence came in such a case. See Gleason v. Commonwealth, 726 S.E.2d 351, 352-53 (Va. 2012); see also Frank Green, Robert Charles Gleason Jr., Who Strangled Two Fellow Prison Inmates, Executed, RICH. TIMES-DISPATCH (Jan. 17, 2013, 12:00AM), http://www.timesdispatch.com/news/robert-charles-gleason-jr-whostrangled-two-fellow-prison-inmates/article_2be8dc8d-92a6-5b8d-ab68-d2fbe9ae8c4f.html (explaining that Gleason plead guilty and told his lawyers not to oppose the death penalty).

80. Unfortunately, the available data made it difficult to identify bargained outcomes with precision. JLARC did not distinguish cases winnowed after indictment by negotiated guilty plea from cases in which prosecutors unilaterally chose not to pursue a death sentence after capital indictment. And the VIDC study was not intended to address case dispositions. Accounts from prosecutors and defense lawyers confirm that dismissal or amendment of capital charges typically occurs pursuant to plea agreement and coincides with a guilty plea to amended charges (usually first degree murder). In reviewing Circuit Court Case Information data on case dispositions, I was able to confirm that pattern in a number of cases reported as resolved by guilty plea or nolle prosequi. Douglass Notes, supra note 71 .

81. See JLARC REPORT, supra note 6, at 12 (reporting views of some prosecutors that the option of life without parole decreased the likelihood they would pursue the death penalty).

82. Id. 
mes plead guilty he available data rts suggest: that bly account for a ials results mostade capital charg.

to resolve capital parole surely has ubt, the option of ath sentences by .gerous offenders $\checkmark$ that tilts away thout parole is on

$\mathrm{ns}$ the decline in e in $1995 .^{82}$ So, to impacts charging JLARC study of ; for most of that

w often such unilateral sations with practitionvely rare.

Gleason v. CommonRobert Charles Gleason TIMES-DisPaTCH (Jan. -charles-gleason-jr-who668-d2fbe9ae8c4f.html oppose the death penal-

ify bargained outcomes dictment by negotiated to pursue a death senled to address case disirm that dismissal or rreement and coincides r). In reviewing Circuit nfirm that pattern in a ui. Douglass Notes, su-

some prosecutors that ould pursue the death impact. ${ }^{83}$ But the capital trial rate has dropped by half since that study. ${ }^{84}$ Something else has happened in the past fifteen years to increase the chances that prosecutors will choose to resolve capital cases short of a contested trial with death still on the table.

That "something," most likely, is a vigorous defense. The most significant change in capital litigation since the days of the JLARC study has been in capital case defense. In 2002 the Virginia General Assembly authorized the creation of four regional CDOs under the supervision of the VIDC ${ }^{85}$ In all capital cases since 2004, Virginia courts have been required to appoint two defense attorneys, including one from a CDO. ${ }^{86}$ State funds were appropriated to staff CDOs with experienced, specialized defense counsel and to provide for investigators and mitigation specialists. At about the same time, Virginia adopted detailed standards for appointment of counsel, increased compensation, and removed fee caps for appointed counsel in capital cases. ${ }^{87}$ It is no accident that the decline in death sentencing coincides with these reforms. A capable and vigorous defense clearly makes a difference, and that defense no doubt accounts-at least in part-for the increased willingness of prosecutors to resolve capital cases short of death.

\section{F. Plea Bargaining: The "Locality Effect"}

Virginia has 121 elected commonwealth's attorneys, one for each independent city or county. ${ }^{88}$ Their views on death penalty charging differ substantially. Many feel it is their public duty to pursue a capital indictment whenever the facts allow. ${ }^{89}$ Others exercise discretion to limit capital charges to the worst of the

83. Indeed, that is one reason the JLARC study chose 1995 as its starting point: to control for any influences that abolition of parole might bring to prosecutors' choices to pursue the death penalty. Id.

84. See supra note 75 and accompanying text.

85. See ABA ASSESSMENT, supra note 16, at 143-44.

86. VA. CODE ANN. § 19.2-163.7 (Cum. Supp. 2014). There are exceptions where the $\mathrm{RCDO}$ has a conflict of interest or where the court finds that appointment of non-CDO counsel is "necessary to attain the ends of justice." Id. § 19.2-163.4.

87. See ABA ASSESSMENT, supra note 16, at 146; JLARC REPORT, supra note 6, at 24.

88. VA. CODE ANN. § 15.2-1626.

89. The JLARC staff surveyed commonwealth's attorneys and reported that "60 percent indicated that they always seek a capital murder indictment when the elements of the offense warrant the charge." JLARC REPORT, supra note 6, at 31. 
worst. $^{90}$ Many defer to the choices of victims' families. ${ }^{91}$ Some choose to avoid capital prosecutions simply because they are too expensive. $^{92}$

It should come as no surprise, then, that location plays a big role in determining who faces capital indictment and who ultimately receives a death sentence. The principal finding of the JLARC study was that "[1]ocation, more than any other factor, impacted the probability that prosecutors would actually seek the death penalty for capital murder cases." ${ }^{\prime 93}$

While capital indictment policies account for some of this "locality effect," most of the difference comes at the plea bargaining stage. According to JLARC, the differential among localities became more pronounced after indictment: capital indictment rates ranged from $72 \%$ in "high density" (urban) areas to $85 \%$ in each "medium density" (suburban) and "low density" (rural) areas, a fairly modest differential. ${ }^{94}$ But things changed as cases moved down the capital litigation funnel. The JLARC study found that prosecutors in suburban localities were almost three times more likely to seek the death penalty all the way through a contested trial or sentencing than prosecutors in urban localities. ${ }^{95}$ In other words, prosecutors differed only a little in their decisions whether to indict capital cases. They differed a lot in deciding whether to bargain for less than death. Hence, primarily as a result of differences in the willingness of prosecutors to plea bargain in capital cases, death sentences were disproportionately a suburban and rural phenomenon in Virginia, at least as late as $1999 .^{96}$

90. See ABA AsSESSMENT, supra note 16, at 118 (describing detailed pre-indictment review practices in one jurisdiction).

91. See id.

92. See id. at 388 (noting the time and expense involved in prosecuting a defendant with mental retardation).

93. JLARC REPORT, supra note 6 , at 29.

94. Id. at 32 fig.11.

95. See id. at 39 fig. 15 .

96. Id. at 28. JLARC noted that such "outcomes ... are not easily reconciled on the grounds of fairness." Id. at Preface. 
families. ${ }^{91}$ Some ıuse they are too

ation plays a big nt and who ultial finding of the any other factor, actually seek the

some of this "loe plea bargaining ıng localities beindictment rates is to $85 \%$ in each "(rural) areas, a $d$ as cases moved study found that three times more rough a contested calities. ${ }^{95}$ In other decisions whether ciding whether to a result of differbargain in capital a suburban and s 1999. ${ }^{96}$

detailed pre-indictment prosecuting a defendant easily reconciled on the

\section{The Future of Virginia's Death Penalty: Assessing FAIRNESS AND CONSIDERING COSTS}

Most public debate about the death penalty focuses on death sentences and executions. ${ }^{97}$ Those, after all, pose fundamental questions: Should the state take life as a sanction for crime? Do we have the capacity to reliably distinguish the guilty from the innocent? Do we make fair choices between those who live and those who die? My aim in this short symposium essay has been to point out a reality that gets obscured in that debate. Death sentences are really the tip of a much larger iceberg of capital litigation. Most of the time, and increasingly over the past twenty years, the practical function of the death penalty is to serve as leverage in a plea bargain. ${ }^{98}$

I offer that as an observation of fact, not as judgment condemning or applauding the trend. ${ }^{99}$ My modest suggestion to policymakers is simply that they should consider the iceberg as well as the tip. We need a careful study to see if our current practices, which depend so heavily on plea bargaining judgments of independently elected prosecutors across Virginia, are fair when viewed in statewide perspective. And we need to consider the

97. See, e.g., Death Penalty, GALLUP, http://www.gallup.com/poll/1606/death-penalty. aspx (last visited Feb. 27, 2015) (demonstrating that the major issues of contention with the death penalty relate to sentences and execution).

98. See supra Part I.E; see also Christopher Solgan, Life or Death: The Voluntariness of Guilty Pleas by Capital Defendants and the New York Perspective, 16 N.Y.L. ScH. J. HUM. RTS. 699, 702 (2000) (explaining that prosecutors use the death penalty in plea agreements); see also Death Penalty Often a Plea Bargaining Tool, DEATH PENALTY INFO. CTR., http://www.deathpenaltyinfo.org/node/1110 (last visited Feb. 27, 2015) (demonstrating that in Ohio most death penalty indictments end in plea agreements). See generally Joseph L. Hoffmann et al., Plea Bargaining in the Shadow of Death, 69 FORDHAM L. REV. 2313 (2001) (discussing the development and prevalence of the death penalty as leverage in plea bargaining).

99. There is a vigorous debate about the appropriateness of plea bargaining in capital cases. A prominent opponent argues that plea bargaining "mocks" or "devalues" the moral position of death penalty proponents, promotes inequality of treatment, increases costs and waste, and devalues the role of defense counsel. See Albert W. Alschuler, Plea Bargaining and the Death Penalty, 58 DePAUl L. REv. 671, 674, 677, 680 (2009). The Supreme Court, by contrast, has held that a defendant's choice to plead guilty to avoid the death penalty does not make the plea involuntary. North Carolina v. Alford, 400 U.S. 25, 38-39 (1970). 
costs, and cost-effectiveness, of a system which charges death more than twenty times for each death sentence it produces. ${ }^{100}$

\section{A. Fairness: Does Winnowing by Plea Negotiation Produce Fair Results?}

Virginia's system of capital litigation winnows out nineteen of twenty capital charges for every death sentence it produces, largely based on plea-bargaining choices by independently elected commonwealth's attorneys. ${ }^{101}$ When JLARC looked at that process for cases now almost twenty years old, it found that the outcomes "are not easily reconciled on the grounds of fairness." more than any other factor, determined the likelihood that a prosecutor would seek a death sentence. ${ }^{103}$

Without another effort like JLARC's detailed statistical study, it is hard to say whether this locality effect has become more or less acute since 1999, or how it may evolve in the future. Ironically, as plea bargaining resolves a greater percentage of cases, we would expect that differences across localities would diminish. Stated more bluntly, if virtually every case results in a bargain for a life sentence, there is little difference in outcomes across localities.

But that kind of future seems unlikely. Inevitably, some cases will not be bargained, and prosecutors will differ in choosing those cases. The trickle of death sentences we have seen in the past decade still tilts toward a few, primarily suburban jurisdictions. ${ }^{104}$ The list of capital indictments in recent years shows comparatively few cases in the state's urban centers and higher numbers in areas of medium or low population density. ${ }^{105}$ If the experience of other states is an indicator, the locality effect will linger, even as death sentencing diminishes. ${ }^{106} \mathrm{We}$ may choose to

100. See supra Part I.D.

101. VIDC REVIEW, supra note 3, at apps. A-B; see supra Part I.D.

102. JLARC REPORT, supra note 6 , at Preface.

103. Id. at 29 .

104. Prince William and Fairfax Counties account for six of the sixteen death sentences in Virginia since 2004. VCCC Data, supra note 20, at Capital Convictions table.

105. See Spreadsheets Listing Capital Murder Indictments from 2008 to 2013 (unpublished data) (on file with the Supreme Court of Virginia Case Management System).

106. See Richard Dieter, The $2 \%$ Death Penalty: How a Minority of Counties Produce Most Death Cases at Enormous Costs to All 9 (2013), available at http:// 
defend that system as a consequence of local democracy. As JLARC observed, it may be harder to defend on grounds of fairness. ${ }^{107}$

Finally, one other factor should give us pause as plea bargaining becomes the principal means for choosing life or death. A bargain requires the defendant's agreement. Some defendants land on death row not because the prosecutor failed to offer a plea to a life sentence, but because the defendant rejected the offer. Indeed, experienced capital defense lawyers estimate that more than half of defendants sentenced to death were offered a plea to life along the way. ${ }^{108}$ At best this system promotes a level of randomness in outcomes of capital cases. At worst it tilts death sentences toward defendants who get poor advice from their lawyers, defendants with mental deficiencies who fail to appreciate the hard choices they face, or defendants with plausible claims of innocence. ${ }^{109}$

\section{B. The Cost Efficiency of Winnowing Capital Cases by Plea Bargain}

We think of plea bargaining as a cost-saving device. When we look only at a single case, we see that a guilty plea saves the cost of trial and (sometimes) of lengthy appeals. But a different picture may emerge if we look at capital cases on the whole, adopting the kind of perspective a legislator might take in assessing the cost efficiency of any criminal justice policy. ${ }^{110}$

Start with costs. Even in a system with heavy reliance on plea bargaining, the choice to bring a capital charge results in substantially higher cost than the noncapital alternative. ${ }^{111}$ That is

www.deathpenaltyinfo.org/documents/TwoPercentReport.pdf (demonstrating the lack of proportion in death penalty sentencing between counties).

107. JLARC REPORT, supra note 6, at Preface.

108. Altschuler, supra note 99 , at 671-72.

109. Thaxton, supra note 25 , at 490 (suggesting that cognitive and emotional deficits make many capital defendants less likely to accept favorable plea bargains).

110. Unlike several death penalty states, Virginia has not yet undertaken that kind of cost-benefit assessment. A recent Kansas study concluded that defending a death penalty case costs about four times as much as defending a capital-eligible murder case where death was not sought. JUD. COUNCIL, KAN. LEGISLATURE, REPORT OF THE JUDICIAL Council DeATH Penalty Advisory CommitTee 15 (2014), available at http://www.death penaltyinfo.org/documents/KSCost2014.pdf.

111. See id.

com 2008 to 2013 (unanagement System).

MINORITY OF COUNTIES 13), available at http:// 
primarily because so much of the added cost of a capital case must be spent before trial. ${ }^{112}$ A recent study in the federal system estimated that capital cases ending in a guilty plea were more than three times as costly as noncapital cases resolved by trial. ${ }^{113}$ Studies from several states echo that finding. ${ }^{114}$ Therefore, Virginia's prevailing pattern of waiting until after indictment to winnow out most capital charges virtually insures high costs, even as it produces few death sentences.

Now consider what we "buy" for those costs. Mostly we buy bargaining leverage. Without detailed study, however, it is hard to know what practical difference that bargaining leverage really makes. Do we get fewer costly trials? Probably not. There is no solid evidence that bringing a capital charge increases the likelihood of resolving the case through a guilty plea. ${ }^{115}$ Indeed, the opposite may be true. ${ }^{116}$ Do we get higher sentences for murderers? For some, probably yes. It does seem likely that, on the whole, prosecutors who charge capital murder will obtain higher bargained-for sentences than prosecutors who negotiate pleas from

112. See Terance D. Miethe, DeP’T OF Criminal Justice, Univ. Of Nev., LAS Vegas, Estimates of Time Spent in Capital and Non-Capital Murder Cases: A Statistical Analysis of Survey Data from Clark County Defense Attorneys 4 tbl.1 (2012) (showing an expenditure of two to four times the attorney hours on the pretrial stage of a capital trial than all other stages combined); see also MOLLY TREADWAY JOHNSON \& LAURAL L. HOOPER, FED. Judicial Ctr., Resource Guide for Managing Capital Cases-Volume I: Federal DEATH PENALTY TRIALS 2 (2004) ("[Capital] cases require early judicial management and substantial pretrial planning because they may involve the most severe form of punishment that society can inflict on its members-death. The process by which the prosecution determines whether it will seek the death penalty is itself time-consuming and demands considerable effort of both the prosecution and the defense.").

113. Thaxton, supra note 25 , at 545 .

114. Id.

115. Compare Ilyana Kuziemko, Does the Threat of the Death Penalty Affect Plea Bargaining in Murder Cases? Evidence from New York's 1995 Reinstatement of Capital Punishment, 8 AM. L. \& ECON. REV. 116, 140 (2006) (concluding that threat of death penalty did not increase the likelihood of a guilty plea), with Thaxton, supra note 25, at 475-76 (concluding that the threat of the death penalty increases the probability of a plea agreement by $20-25 \%$, an amount insufficient to offset the added costs of capital cases that go to trial).

116. In Virginia, despite the high number of bargained-for resolutions in capital cases, the rate of trial in capital cases still exceeds the trial rate for noncapital cases. See supra Part I.E. I estimate a capital jury trial rate of about $8 \%$ and a similar bench trial rate of $8 \%$ in the past five years. See supra Part I.D. The rate of jury trials in Virginia in felony cases in 2013 was $1.2 \%$, and the rate for felony crimes against the person was $4.4 \%$. VCSC REPORT, supra note 70 , at $30-31$. Bench trials accounted for $9 \%$ of all felony convictions. Id. 
a capital case federal system llea were more Jlved by trial. ${ }^{113}$ erefore, Virginnent to winnow osts, even as it

Mostly we buy ever, it is hard leverage really oot. There is no eases the likeliIndeed, the opfor murderers? , on the whole, ain higher bar;iate pleas from

OF NEV., LAS VEGAS, A Statistical Analysis (showing an expendia capital trial than all JRAL L. HOOPER, FED. -VOLUME I: FEDERAL cial management and evere form of punishwhich the prosecution ssuming and demands

nalty Affect Plea Bar. ement of Capital Punareat of death penalty ra note 25 , at $475-76$ ability of a plea agreef capital cases that go

ttions in capital cases, apital cases. See supra lar bench trial rate of $\mathrm{s}$ in Virginia in felony erson was $4.4 \%$. VCSO all felony convictions. the starting point of an indictment for first degree murder. ${ }^{117}$ But the difference may be more symbolic than real. The threat of a death sentence may induce a plea to life without parole. Still, even without that leverage, a plea to first degree murder likely will keep the convict in prison well into old age. ${ }^{118}$ The practical difference may be a few years of geriatric release.

Virginia's budget-makers may differ in their assessments of these costs and benefits. My point is simply that they should not undertake that assessment without recognizing the pervasive influence of current charging and plea-bargaining practices.

\section{CONCLUSION-A MODEST SUGGESTION FOR REFORM BY NARROWING THE FUNNEL}

Virginia could substantially reduce the statewide costs of its death penalty system with little change in the ultimate outcome of capital cases. To do so would require winnowing out at the indictment stage some of the cases that currently get winnowed after indictment; narrowing the top of our capital litigation funnel before we spend millions litigating cases that will be bargained down to lesser sentences anyway. We could accomplish that through a variety of means, steps that would bring the added benefit of consistency to a system now characterized by differences based on locality.

Without changing the fundamental structure of local control, we could encourage more exacting review at the indictment stage. A few commonwealth's attorneys have developed policies for that purpose. ${ }^{119}$ At the federal level, the Department of Justice requires extensive pre-indictment review. ${ }^{120} \mathrm{An} \mathrm{ABA}$ study recommended that Virginia commonwealth's attorneys develop advisory guidelines or consultative processes to guide discretion in bring-

117. See Kuziemko, supra note 115, at 116, 140

118. On average, defendants convicted of "more serious" first degree murder in Virginia serve forty-five years. VA. CRIM. SENT'G COMM'N, A DECADE OF TRUTH-IN-SENTENCING IN VIRGINIA 2, available at http://www.vcsc.virginia.gov/Mar_05/TIS_Brochure.pdf (last visited Feb. 27, 2015).

119. ABA ASSESSMENT, supra note 16, at 117-19.

120. See DEP'T OF JUST., U.S. ATTORNEYS MANUAL 9-10.030-.040 available at http: //www.justice.gov/usao/eousa/foia_reading_room/usam/title9/10mcrm.htm\#9-10.030 (last updated April 2014). 
ing capital charges. ${ }^{121}$ Some states have adopted similar guidelines. ${ }^{122}$ Any of these steps would help to address the concerns over fairness that JLARC highlighted more than a decade ago, and save money in the process.

There is a simpler and more effective way to limit capital litigation costs with little change in outcomes. Remove robbery, standing alone, as a predicate for capital murder. ${ }^{123}$ That statutory change alone would reduce the iceberg of capital litigation by about half. ${ }^{124}$ The JLARC study found that robbery-murder cases account for more capital murder indictments than all other predicates combined. ${ }^{125}$ Yet cases where robbery is the only predicate almost never result in a death sentence. ${ }^{126}$ Indeed, had Virginia made that change to its capital murder statute ten years ago, it would have saved millions in cost without affecting a single death sentence. ${ }^{127}$ It would have made our system more consistent across localities, and we would have preserved the charging authority of commonwealth's attorneys.

Capital cases are expensive. They should be with so much at stake. I do not suggest that we reduce costs by cutting corners in investigation, prosecution, or defense of individual cases. Nor do I argue that plea bargaining has no place in capital cases. I only observe that Virginia's capital litigation system has achieved a very costly equilibrium. We indict a comparatively high number of death cases. Then, after substantial expense, we almost always bargain them away for noncapital results. We have invested heavily in a death penalty that serves mostly as a bargaining chip. As we consider the future of Virginia's death penalty, that state of affairs should concern policy makers, regardless of their views on the death penalty.

121. See ABA AsSessment, supra note 16 , at 120 \& n.63.

122. Id. at 120 n.63.

123. This would mean repealing Virginia Code section 18.2-31(4) (Repl. Vol. 2014).

124. The JLARC study found that $56 \%$ of capital murder indictments had robbery as the sole predicate. JLARC REPORT, supra note 6, at 30 fig. 10.

125. The JLARC study found that $56 \%$ of capital murder indictments had robbery as the sole predicate. JLARC REPORT, supra note 6 , at 30.

126. See VCCC Data, supra note 20.

127. Id. 